\title{
Management of the Wadden Sea
}

\author{
W. J. Wolff ${ }^{1}$ \& J. J. Zijlstra ${ }^{2}$ \\ ${ }^{1}$ Research Institute for Nature Management; Texel, The Netherlands, \\ and \\ ${ }^{2}$ Netherlands Institute for Sea Research; Texel, The Netherlands
}

\begin{abstract}
The Wadden Sea situated along the North Sea coasts of Denmark, the Federal Republic of Germany and The Netherlands represents one of the world's largest bar-built type of estuaries. The area is a typical sedimentation and mineralization basin, with a large influx of organic matter from the adjoining North Sea, consequently a delicate oxygen balance and a rich benthic macrofauna, poor in species, which serves as food for juveniles of some commercially important North Sea fishes and for large numbers of migrating and wintering waders and waterfowl. Past and present activities of the human society in the area include fisheries (mainly for shrimp and mussels, semi-culture), shipping, land reclamation, recreation, dredging for sand and shells, and waste discharge from industries and human communities. Until the present these activities, although sometimes conflicting, did not fundamentally affect the area and its biota (pollution excluded), but future claims, including the construction of large deep-sea harbours, drilling for natural gas and oil, large-scale land reclamation and increased industrialization etc., might gradually induce degradation. For instance, area reduction by continued land reclamation could lead to irreversible losses of specific biotopes (e. g. salt-marshes, mud-flats), which could affect the size of bird and fish populations in a much wider region. Increased pollution, which has already inflicted damage on bird and seal populations, could reduce the fauna and hence the value of the area as a natural sanctuary. In the event of a proposal for a new human activity in the area, the present standing practice in the countries concerned requires an evaluation of its safety and economic aspects and its environmental impact. However, the various plans are considered separately and there is a general need for integrated management of the area.
\end{abstract}

\section{INTRODUCTION}

Contrary to the situation on land, where management of areas either in relation to agriculture, forestry, industry and urban development or directed to conserve a natural or semi-natural environment has long been common practice, management of areas in the world oceans is a rare phenomenon, and of recent date. Obviously, this is due to the fact that the interests of man - fundamentally a terrestrial species - in the oceanic part of our world were until quite recently restricted, concerned mainly with shipping, fishing and, in coastal areas, land reclamation and defences against the sea. Only in this century, in particular in its latter half, has management of sea areas developed, e. $\mathrm{g}$. in relation to shipping (sea-lanes), oil and gas exploitation, sand and gravel extractions, fisheries and mariculture (mussel and oyster beds). Locally marine areas have been set apart as nature reserves, although in several of these commercially exploited recreation is detrimental to flora and fauna. Such reserves are often in areas with coral reefs. The impact of these activities was felt in some cases only on the species level, either because 
an unlimited expansion of fishing fleets, often combined with technical improvement of fishing methods, resulted in a steep decline of fishing yields or because unrestricted hunting of mainly marine mammals led to near-extinction of some species. The impact of man on marine ecosystems was, until recently, very limited.

Considering the rapid increase of man's interest in the sea in recent years, as apparent from the expansion of the number of man's activities, improved technical possibilities and the imminent change in the juridical system for the sea, a growing interference of man with the world ocean may be anticipated. Although this impact might and probably will affect all parts of the ocean, including the deep sea (mining for manganese nodules, oil-drilling) the effect is already most strongly experienced in shallow, coastal seas, due to their accessibility to man and the proximity of often densely populated coastal lands.

This paper intends to describe as an example the merits, threats and possible management of such a coastal sea, the Wadden Sea. The area concerned is situated in the southeastern North Sea and is bordered by one of the world's most densely populated and most highly developed coastal lands. Although barrier islands and a coastal region form an integral part of the area, the emphasis in this paper will be on that part of the region affected directly by the tidal waters.

\section{DESCRIPTION OF THE AREA}

The Wadden Sea, a shallow sea area along the north coast of the Netherlands, the coast of the Federal Republic of Germany and part of the west coast of Denmark, covers an area of some $8000 \mathrm{~km}^{2}$ extending over more than $500 \mathrm{~km}$ of coastline. The area is bounded on the seaward side by a belt of barrier islands, between which deep tidal channels form the connection with the North Sea (Fig. 1). These tidal channels branch into an intricate system of gullies and creeks, formed and maintained by tidal water transport. In general each of these tidal channels drains a particular basin, the various basins being separated by tidal "watersheds" behind the islands. The tidal amplitude varies in the area between $1.5-4 \mathrm{~m}$ and during the ebb vast areas of bare tidal flats emerge, which cover over half the region at low tide (Fig. 2).

Although some large rivers and other freshwater outlets discharge into the Wadden Sea, causing somewhat reduced salinity as compared with the open sea (normally 20-30\% $\mathrm{S}$, with a range to freshwater in river mouths), the area can hardly be characterized as an estuary. Geomorphologically its existence seems to depend mainly on the combined presence of a gently sloping coast, an ample supply and a land-directed transport of finer sand and silt by the tidal currents and a slow rise in sea level, relative to the land. The tides and the relative rise in sea level are also responsible for the dynamic character of the landscape, apparent from historical studies (van Straaten, 1965). Thus, on a longer time scale (centuries) extensive shallow bays have silted up, the islands seem to have travelled eastwards and coastwards and the main tidal inlets have become shallower or have deepened, whereas during shorter time spans (years) gullies and creeks have evolved, disappeared or changed their course.

The character of the sediment changes gradually from coarser sand in the main tidal channels to fine silt on higher ground along the mainland and behind the islands, depending on the velocity of the tidal currents and exposure to wave action. Parallel to 


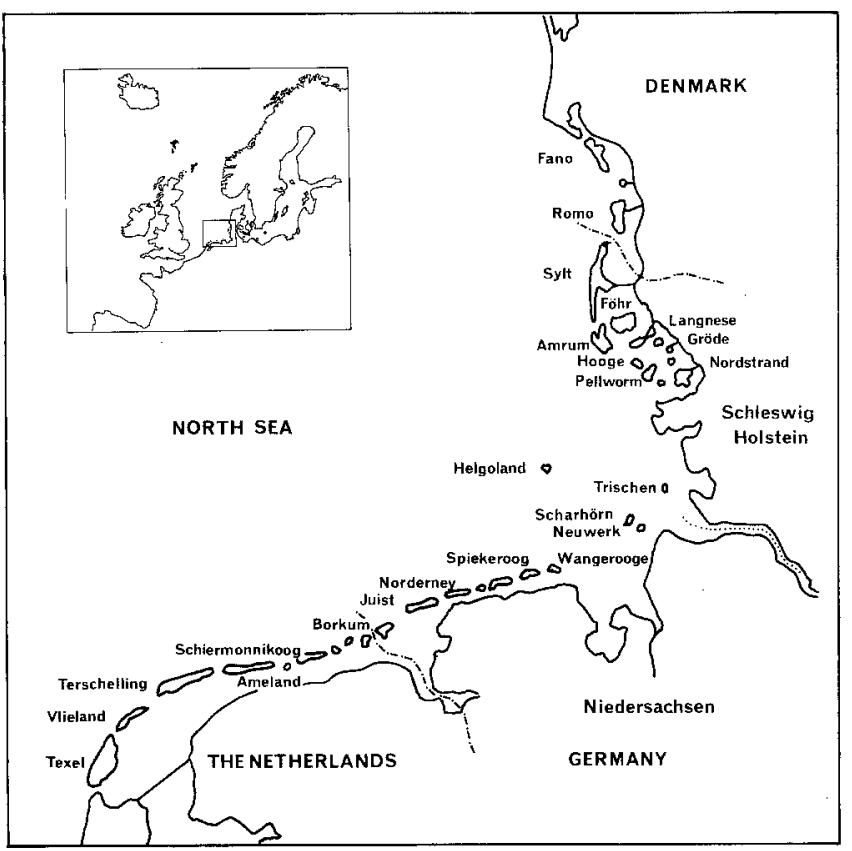

Fig. 1. The Wadden Sea area

this change in sediment type is a change in the turbidity of the water, low at the entrances to the Wadden Sea and high deeper in the basins.

Biologically the area is characterized by an absence of vascular plants (except for seagrasses) below high water mark, although salt-marshes are present just below and above that line, within reach of storm floods. This distinguishes the Wadden Sea from similar areas as for instance along the east coast of North America, where the tidal flats are covered with Spartina vegetation.

Other important biological characters are the rich benthic macrofauna, living for an important part on and in the bare tidal flats (Linke, 1939; Smidt, 1951; Beukema, 1976) and its delicate oxygen balance with a somewhat reduced oxygen concentration in the water in summer (de Groot \& Postma, 1968) and anoxic conditions in the finer sediments (Vosjan, 1974). These conditions seem to indicate a high supply of primary organic matter. However, estimates of primary productivity by unicellular algae, both planktonic and on the tidal flats, are not exceptionally high, probably due to light limitation in the turbid water; they range from $100-200 \mathrm{~g} \mathrm{C} \mathrm{m}^{-2} \mathrm{y}^{-1}$ (Cadée \& Hegeman, 1974a, b; Cadée personal communication). The contribution of larger algae and vascular plants in the channels, on the flats and in the salt marshes seems negligible in comparison (van der Hoek et al., 1979; Joenje \& Wolff, 1979).

Apparently of much greater importance for the biological fueling of the area is the net transport of dead and living suspended material into the Wadden Sea, originating from the adjoining North Sea as suggested by Postma (1954) and de Jonge \& Postma (1974). This process, partly of physical (Postma, 1961) and partly of biological origin 


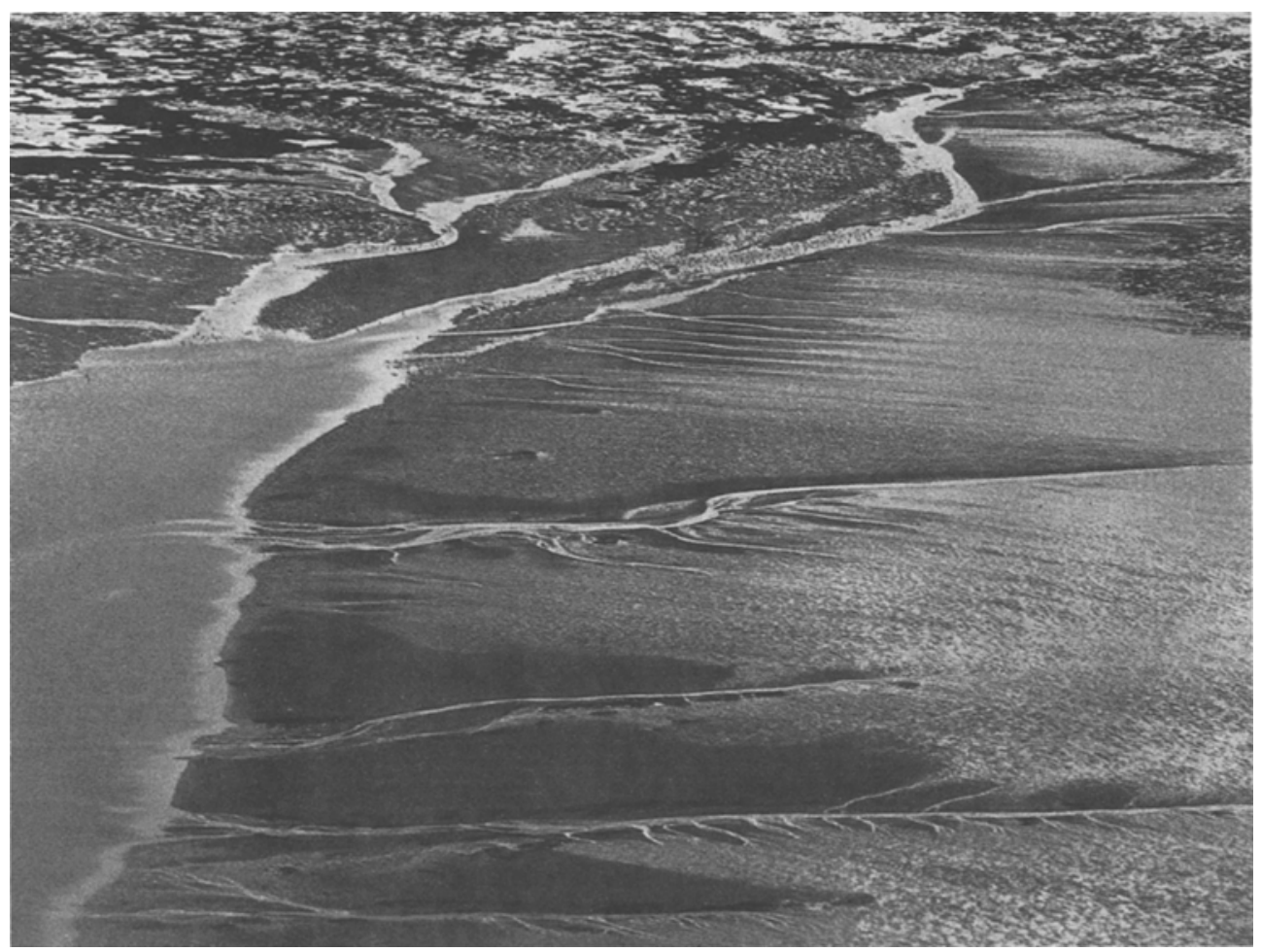

Fig. 2. During ebb tide extensive tidal flats emerge in the Wadden Sea

(Verwey, 1952) results in a net import of organic carbon of about the same magnitude as that locally produced.

A considerable part, possibly more than half, of all primary organic matter present in the area seems to be decomposed by micro-organisms (de Jonge \& Postma, 1974). Mineralization in the sediments is indicated to be of major importance (Vosjan, 1974; van Es, 1977), while a large part of the organic matter reaching the sediments seems to be decomposed under anoxic conditions by sulphate-reducing bacteria (Vosjan \& Olanczuk-Neyman, 1977). Therefore, an important aspect of the area is that it acts as a mineralization basin, receiving large amounts of mainly dead organic matter from the open sea and returning the inorganic components.

Part of the primary food supply, supplemented by bacteria directly or via ciliates (Fenchel \& Barker Jørgensen, 1977; Berk et al., 1977), finds its way to higher parts of the food chain. Of these the benthic macrofauna is most conspicuous, although the zooplankton, less well studied, may be of equal importance in terms of production (Fransz, in press). This zooplankton, which includes a large proportion of meroplankton, shows great exchange with the neighbouring North Sea, due to the usually short residence time of the water in most Wadden Sea basins (Zimmerman, 1976).

The benthic fauna, dominated not only in terms of biomass but possibly also in production by the macrofauna, is conspicuous not so much for its species diversity as for 
its mass occurrence in a very extensive area. Only six species (molluscs, polychaetes), common in all estuarine habitats of northwestern Europe, contribute substantially to the benthic biomass. Mussel banks are locally well developed in creeks and gullies, but in general the benthic fauna is most abundant on the tidal flats, reaching on average a biomass of about $27 \mathrm{~g}$ ash-free dry weight $\mathrm{m}^{-2}$ (Beukema, 1976). This figure should be compared with the $3-5 \mathrm{~g} \mathrm{~m}^{-2}$ found on average in the North Sea (McIntyre, 1978). The benthic macrofauna in the Wadden Sea is almost certainly favoured by the high density of food particles present, but also by the shallowness of the area and the absence of stratification, so that food particles suspended in the whole water column are at the disposal of the benthic community. Moreover, the tidal currents transport those food particles, preventing a local depletion of the food supply. Under such circumstances one would expect a dominance of suspension-feeders, as indeed has been observed (e.g. Beukema, 1976). However, whether food is the only factor responsible for the high

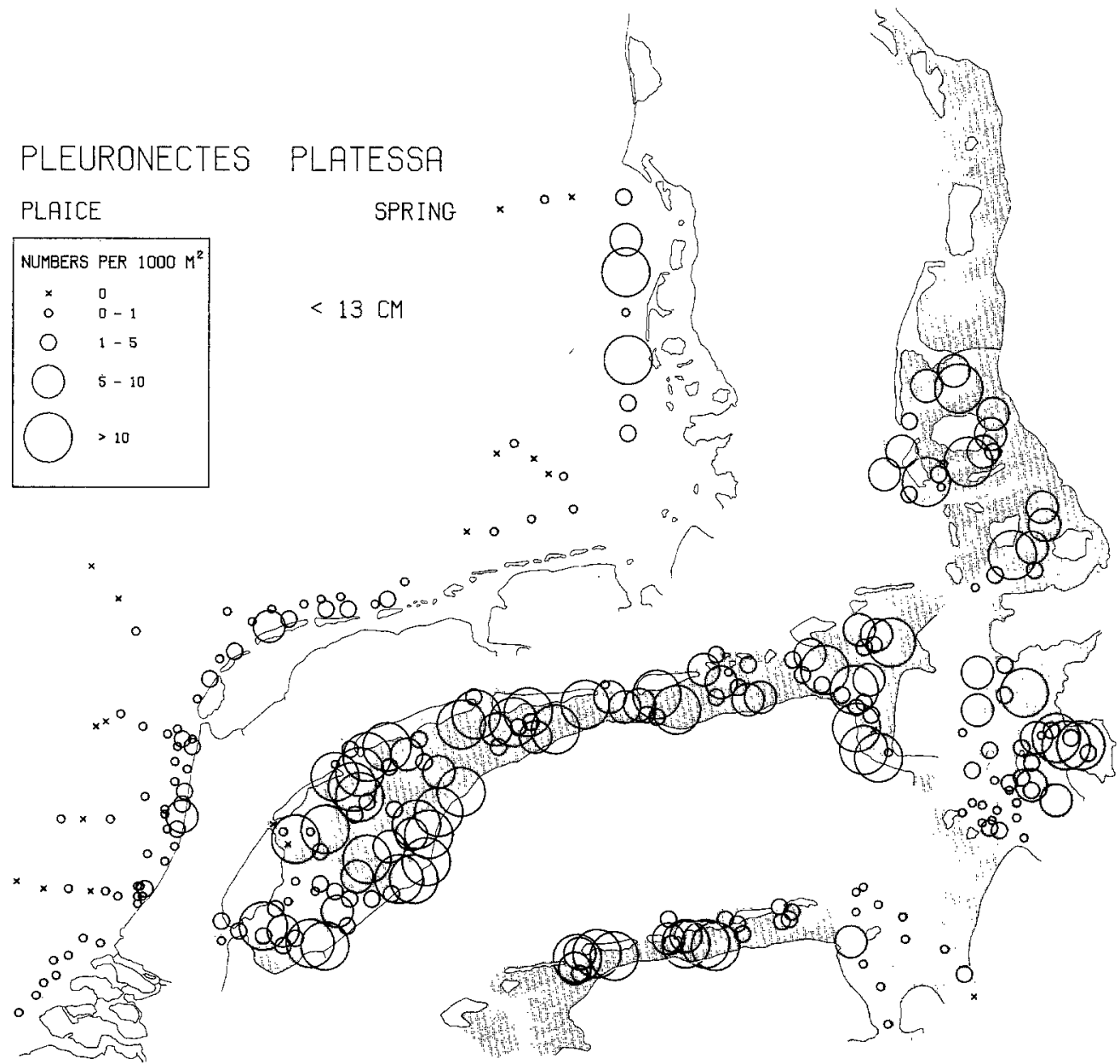

Fig. 3. Distribution of 0-class plaice (Pleuronectes platessa) in the Wadden Sea and adjacent North Sea in autumn (after Dankers \& de Veen, 1979) 
abundance of the macrofauna seems doubtful. Various abundant species occupy nursery areas on high level mud-flats as for instance Arenicola marina (Farke et al., in press), Macoma balthica (Beukema, 1973), Carcinus maenas (Breteler, 1976) and Crangon crangon (Kuipers, personal communication), thereby evading possible predation by larger crustaceans and fishes; this might be an important factor in the Wadden Sea (Reise, $1977 \mathrm{a}, \mathrm{b}, 1978$ ). As, moreover, growth rates show only small variations in abundant organisms (Beukema, personal communication), biomass and production of the macrofauna mainly depend on the supply of juveniles (recruitment) and hence probably on predation in combination with abiotic factors.

Two other major biological aspects of the Wadden area depend on the abundance and high productivity of the macrofauna, i.e. its function as a nursery area for some commercially important North Sea fish species (Zijlstra, 1972) and its role as a feeding and resting ground in all seasons for a number of local, sub-arctic and arctic waders, ducks and geese (Swennen, 1976b). From the distributional pattern of juvenile plaice (Pleuronectes platessa), sole (Solea solea) and possibly herring (Clupea harengus) the Wadden Sea acts as the major nursery for the North Sea populations of these species (Fig. 3). The nursery function is probably of much greater importance for the North Sea fisheries as a whole than the local catch, which consists mainly of mussels (Mytilus edulis) and shrimps (Crangon crangon) (Postuma \& Rauck, 1978).

The vital role of the Wadden Sea in supporting large populations of birds has been documented by several authors (Rooth, 1966; Swennen, 1976b; Saeijs \& Baptist, 1978); the routes of migratory shore birds are illustrated in Figure 4 . The Wadden Sea provides not only a food supply, but also resting places during high tide when food is not available to waders and a quiet refuge for moulting birds.

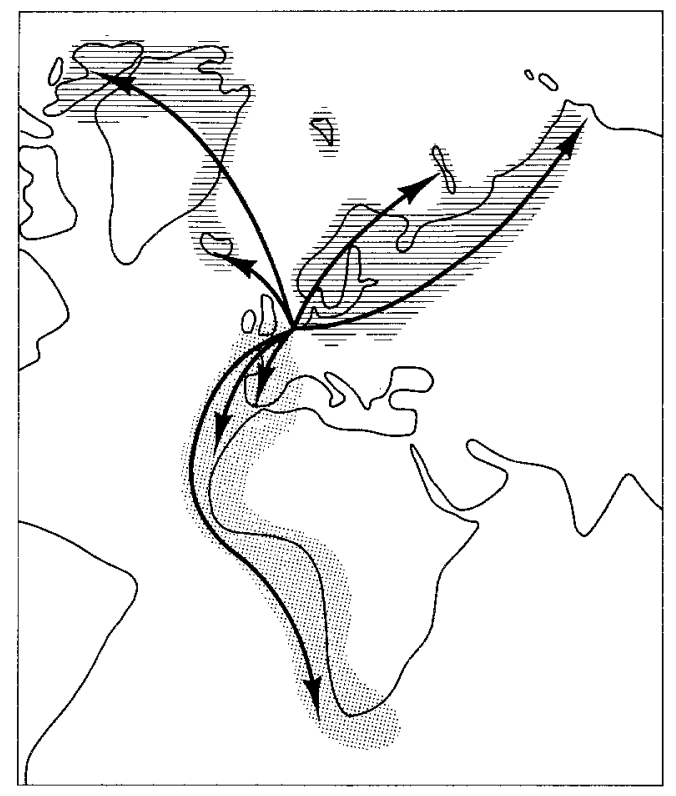

Fig. 4. Areas of origin and winter distribution of migratory shore birds passing the Wadden Sea 
The majority of the birds and flatfishes profit from the abundant food present in the Wadden Sea in the form of benthic macrofauna. Exploitation of this fauna depends on the mass occurrence of only a few species, facilitating easy specialization. Such specialization has been shown in the case of plaice by Kuipers (1975) and for some bird species by Hulscher (1976) and Swennen (1971, 1976a). Birds and fishes probably take an equal and considerable part of the annual production of the benthic macrofauna.

Finally, the Wadden Sea is inhabited by a population of harbour seals (Phoca vitulina), which visits the area at least for whelping and mating during the summer season. In recent years the population in the western Wadden Sea has greatly declined (Reijnders, 1976), probably due to a still unknown pollution factor.

\section{FUNCTIONS OF THE AREA FOR HUMAN SOCIETY}

Through the ages man has been active in the Wadden Sea by exploiting its resources and making use of its possibilities for transport and land reclamation. The main occupations of man in the area, in the past and at present, fall into three different categories.

\section{Sea defences and dams}

Along the edges of the tidal areas man built dikes and other constructions to protect his own terrestrial habitat on the mainland and the islands or to connect islands to the mainland. In several cases these constructions had and have an impact on the Wadden Sea system (Zuiderzee, Lauwerszee, Hindenburgdam, Rømødam).

\section{Losses of area}

Parts of the Wadden Sea area have been changed into completely different types of systems which no longer have a close relationship to the tidal systems. The main examples may be listed as follows:

(1) Land reclamation for agricultural purposes has been practised for nearly a thousand years.

(2) Recently parts of the area have been reclaimed as fresh water storage $\mathrm{b}$ a $\mathbf{s}$ i $\mathbf{n} \mathbf{s}$, either for drinking water or to improve the drainage of the hinterland.

(3) H a r b o u r s used to be sheltered parts of the tidal area, but the larger ports are nowadays areas of a completely different nature, which can no longer be considered to be part of the Wadden Sea system.

\section{Functions of the Wadden Sea proper}

Traditionally the Wadden Sea proper had a number of uses for human society. New functions have evolved during our century; for some of these the area merely provides a physical substrate, whereas others require the existence of a well-functioning ecosystem. The main functions at present may be listed in a sequence reflecting an increasing dependence on the ecosystem as follows. Wolff (in preparation) provides a more detailed list. 
(1) S h i p p in g. Apart from local sea traffic to the islands, the area was and is used for transport of goods to and from more distant parts of the world.

(2) Military training sites. These occur nowadays especially in the Dutch part of the Wadden Sea, but in other periods they have also been used elsewhere (Knechtsand).

(3) Mining. In the area natural gas, sand and shells are exploited.

(4) Waste discharge. Waste is discharged from industries as well as from towns and villages. The Wadden Sea is influenced by waste led into the area itself as well as by pollution transported by sea currents and tides into the area.

(5) Recreation includes coastal and island tourism, yachting, walking across the tidal flats, bird watching, sport fishing and hunting.

(6) Fis heries. This concerns both the local fisheries for shrimps and cockles as well as the area's nursery function for some North Sea fish species. The mussel culture is also included.

(7) Warning system for environmental deterioration, for instance by a mass-mortality of birds as occurred in the middle sixties (Koeman, 1971; Rooth \& Donkers, 1972; Swennen, 1972) or by a gradual decline as presently experienced in the seal population, due to still unknown agents.

(8) $\mathrm{S}$ cientific rese a $\mathrm{ch}$. In recent proposals to give the area the status of a nature reserve or a sanctuary, the latter four functions have been emphasized. However, there is also a growing tendency to preserve the Wadden Sea as a whole for its own merits as a wilderness area. In such a sanctuary plants and animals which are threatened with extinction elsewhere should find a place for survival. The Wadden Sea would then be beneficial not only to human society but also to its plants and animals. Human activities in the area would only be permitted insofar as they were not detrimental to the ecological characteristics of the systems.

\section{CONFLICTS BETWEEN FUNCTIONS AND DANGERS TO THE AREA}

Even a cursory examination of the various human activities reveals that conflicts are bound to occur. However, as long as the various activities are executed on a small scale, such conflicts never become manifest.

To illustrate the situation with a striking example, it is nowadays possible to close off most of the Wadden Sea by building dams between the islands and reclaiming the entire area. Such a major operation, which was more or less seriously considered in Denmark and the Netherlands in the midsixties (Anonymous, 1974; Jacobsen, 1976) (Figs 5,6), would have brought an abrupt end to most functions of the Wadden Sea in their present form. However, various activities could be continued, either in a different area (shipping, harbours, protection against the sea, waste-discharge) or under different, even more convenient conditions (mining, military training sites). It is mainly because of the discrepancy between the costs and the benefits as well as the loss of a natural sanctuary (birds, seals), the losses to fisheries and to recreation that these drastic plans have been abandoned.

However, there are also smaller conflicts, as will be illustrated in a number of examples. 


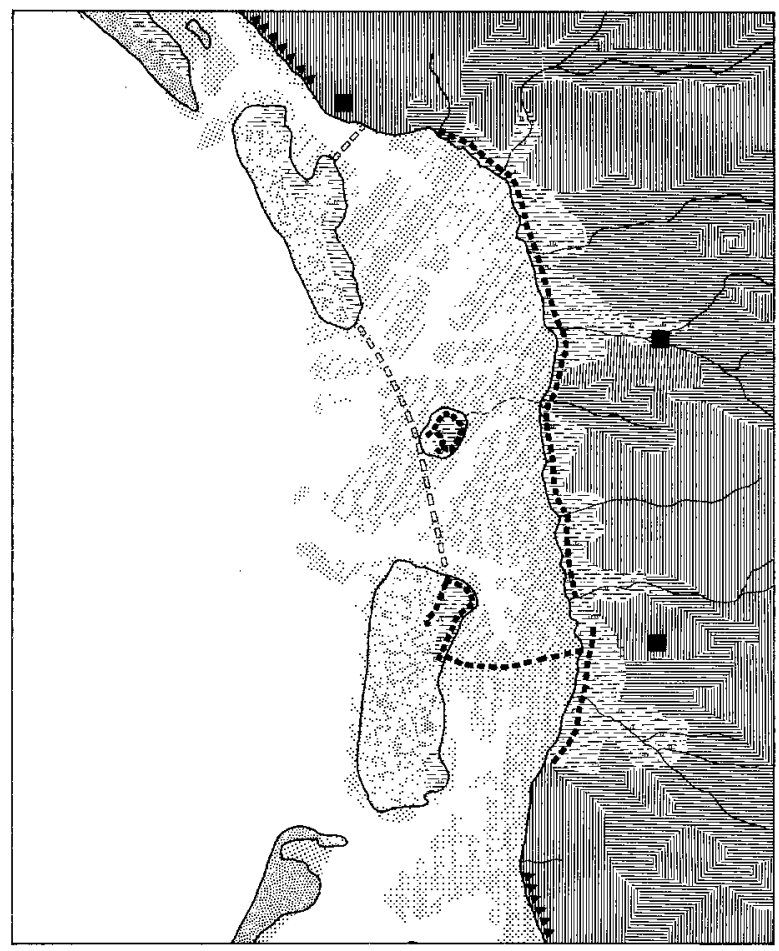

Fig. 5. Proposed and rejected reclamation scheme for the Danish Wadden Sea (after Kingo Jacobsen, 1976)

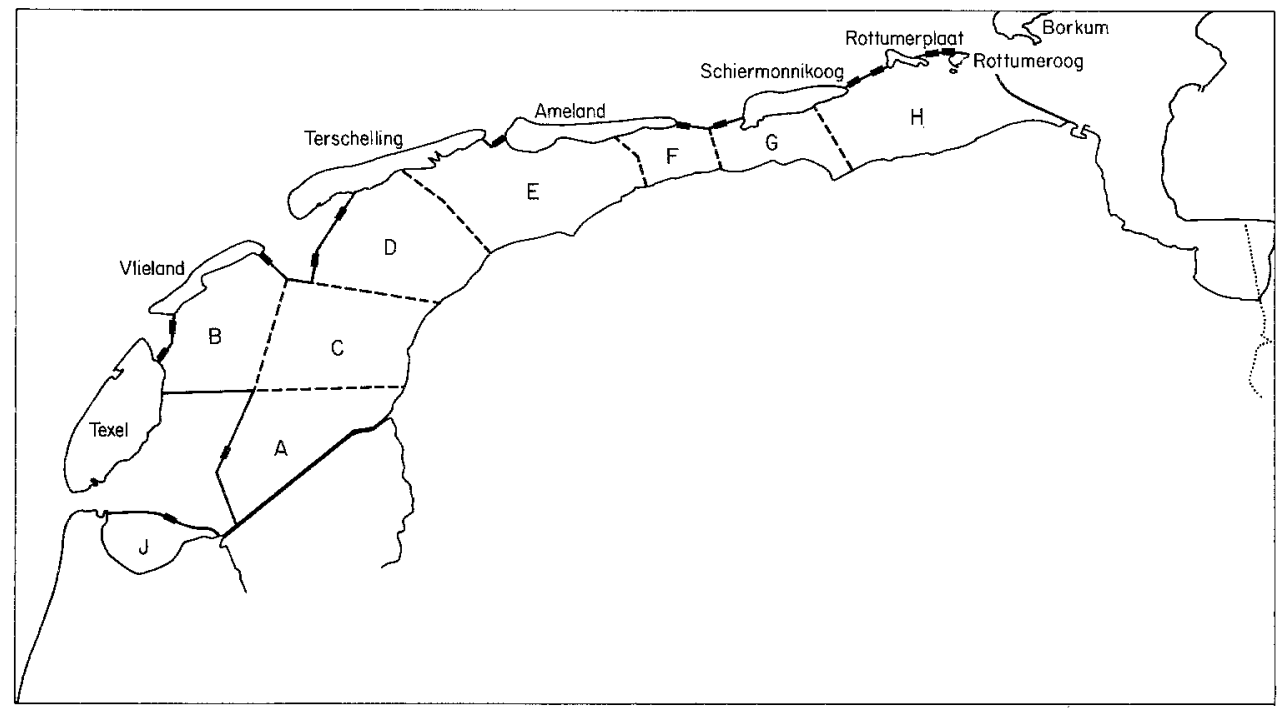

Fig. 6. Example of a reclamation scheme for the Dutch Wadden Sea (after Anonymous, 1974). This and similar schemes have been rejected after ample consideration 
(1) One conflict situation concerns an important local fishery concentrating on shrimp and using fine-meshed nets. There the numbers of juvenile plaice and sole of a year-class caught and destroyed are of the same order of magnitude as those recruited to the North Sea fisheries (Tiews, 1978). This situation has been defended by pointing out that mortality in juvenile fish is high and possibly density-dependent so that removal of the juvenile fish causes mortality which would have occurred anyway. Recent studies tend to confirm this high, density-dependent mortality (Rauck \& Zijlstra, 1978), but later studies suggest it to occur mainly prior to the catch by the shrimpers. Nowadays, the shrimp-boats tend to exploit more off-shore grounds, where immature plaice and sole are less numerous and the conflict might be abating.

(2) In all three countries bordering the Wadden Sea requests have been made for the construction of new, stronger and higher dikes, in front of existing sea defences and primarily aiming at better protection of the hinterland. Such operations would mean the loss of salt-marshes, high-level mud-flats and in some cases sandy flats. The resulting reduction in area might affect the fisheries directly, if indeed the number of plaice, sole and shrimp naturing in the Wadden Sea depends on the size of the area. Furthermore, the loss of high-level mud-flats, which present important nursery areas for some members of the benthic macrofauna, might reduce the food resources of both fish and bird populations. It is uncertain whether new high-level mud-flats and salt-marshes will be formed in front of the new dikes. Finally, birds might lose vital high-tide resting sites, and salt-marshes, of which few remain along the main coast, might be permanently lost.

Therefore, land-reclamation activity, aiming at agricultural advantages and better defence against the sea, could interfere with fisheries, with certain aspects of recreation and with conservational aspects.

(3) Until recently sand and shell extraction in the Wadden Sea was considered as a quite harmless activity. However, there are now indications that due to the dynamic character of the marine part of the Wadden Sea the pits, resulting from these operations, will be filled in by sediment derived from the coastal area around the barrier islands, thereby weakening coastal defence. On a much larger scale similar shifts in coastal sediments might occur if the exploitation of gas (or oil) resulted in a lowering of the seabed in the Wadden Sea. Therefore, mining in the area proper or in its immediate surroundings might result in a weakening of the protection of the mainland, the area offers against the sea, in addition to possible harmful effects due to pollution. Sand and shell extraction might, apart from disturbing the sediment balance in the area, increase the turbidity of the water, at least temporarily, which seems to affect the macrofauna and could hence influence the fisheries and the bird populations.

(4) Pollution in the Wadden Sea due to waste disposal concerns partly organic waste derived either from human aggregates or from agricultural industries (e.g. potato-flour mills). Although such organic waste discharge may cause problems locally, e.g. anoxic

Table 1. Sources of organic matter to the Dutch Wadden Sea (after Essink \& de Wolf, 1978)

Primary production in situ

Supplied by the North Sea

Discharge of organic waste
$29 \times 10^{4}$ tons C year $^{-1}$

$58 \times 10^{4}$ tons $C$ year $^{-1}$

$6.5 \times 10^{4}$ tons $C$ year $^{-1}$ 
conditions in restricted areas, the total amount of organic matter discarded is small in comparison with that present due to natural processes (Table 1; Essink \& de Wolf, 1978). Moreover, increasing sewage treatment reduces the problem.

More serious is increased import of organic matter, probably dead planktonic organisms, from the North Sea, as reported for the western part of the Wadden Sea. This is thought to be related to the eutrophication of the coastal zone of the North Sea due to an increased discharge of plant nutrients (mainly phosphorus) by the rivers (e.g. Rhine) (de Jonge \& Postma, 1974). This situation, which is difficult to control as sources are diffuse, could eventually disturb the delicate oxygen balance in the Wadden Sea and lead to general degradation of the area (van Bennekom \& Tijssen, 1976).

Equally serious is pollution by toxic chemicals such as chlorinated hydrocarbons and heavy metals which reach the Wadden Sea mainly through river and other freshwater discharges (Wellershaus, 1978). The pollutants in the Dutch part of the Wadden Sea are mainly derived from the Rhine system and transported through the Dutch coastal area. Some pollutants reach the Wadden Sea dissolved in water, but others (metals) are absorbed to particles which concentrate and settle in the area (Duinker \& Koeman, 1978).

Only in few cases could animal mortalities occurring in the Wadden Sea be traced to a particular pollutant. The best-known example is heavy bird mortality, in particular of sandwich terns and eider-ducks, due to pesticides (dieldrin, telodrin, aldrin): When production of the pesticides was discontinued, the bird populations recovered (Koeman, 1971; Rooth \& Donkers, 1972; Swennen, 1972).

However, more potentially toxic pollutants have been demonstrated in the area while some animal populations show an unexplained decline, as for instance the harbour seal in the Dutch Wadden Sea. It is often extremely difficult to connect a gradual decline of species with a specific pollutant, so that pollution, originating for a large part from waste disposal sites outside the Wadden Sea, will pose a danger for the area for a considerable period to come. Oil pollution may also present a serious problem. It is true that in general oil pollution of the North Sea has abated in the last ten years, since the Convention of London took effect. However, small-scale oil pollution, partly derived from harbours in the Wadden area proper but also from oil discarded at sea and entering the area via the inlets, is still present and takes a significant toll of the bird population. The most serious problem here, however, is the imminent danger of a large-scale oil spill comparable to the "Torrey Canyon" or "Amoco Cadiz," for which no satisfactory solution has as yet been found. Such a spillage would almost certainly cause a major disaster.

Therefore, waste disposal either in the area proper or in its approaches, which are difficult to define, might impair the fisheries, recreation, scientific research and conservational functions of the Wadden Sea.

It will be clear that apart from the four examples given more potential conflicts between functions can be imagined. For instance, shipping and the construction of deepsea harbour facilities, with the accompanying industrial development, can be poorly reconciled with sea defences (sand extraction), fisheries, recreation and nature conservation (pollution, etc.). Unrestricted recreation is able to disturb the area by the construction of marinas, pollution, general disturbance, etc. 


\section{MANAGEMENT OBJECTIVES}

In the past the natural forces acting in the Wadden Sea set a limit to man's activities in the area, restricting them to a comparatively low and opportunistic level. Conflicts between activities, if existing at all, never became manifest. Now, however, man has the means to influence and even to change completely any aspect of the Wadden Sea system. Hydraulic engineering and mining technology are nowadays primarily restricted by economic prospects and political preferences. Pollution has been shown to exert its influence everywhere in the Wadden Sea. Tourism is able to disturb any place in the Wadden Sea and in fact usually does so. Therefore, it can be expected that, as has been shown in the preceding section, conflicts between functions of the area will occur and more can be envisaged.

In the case of conflicts between functions, those dependent on a well-functioning ecosystem tend to be at a disadvantage. Unrestricted fulfilment of one or more functions may severely impair the performance of any other function. It may be expected that in the absence of management, mainly short-term economic advantages and short-sighted political arguments will decide the course of events. This will result in an area deprived of most of its present values for nature conservation, fisheries and tourism. If one is not willing to accept such a situation, governmental management of the area is inevitable.

In formulating a management objective there are various ways to solve the problem of conflicts between functions:

(1) Only functions which do not interfere with each other should be allowed in the area.

(2) Conflicting functions are allowed and a decline of the fulfilment of each function is accepted.

(3) Functions are positioned in a hierarchical system, implying that a low-ranked function should not (or only slightly) impair a higher-ranked function.

The first strategy is unrealistic since actual or potential conflicts are inherent in nearly any set of functions. The second approaches the present situation, but we believe that the third strategy provides the best chances for preserving the present values for nature conservation, fisheries and recreation. Of course, this is only possible if these "soft" functions are ranked high in the hierarchy. However, this does not solve all problems as may be illustrated with the following examples. In each of these examples one of the above-mentioned functions is given top rank and any other function is not allowed to interfere with the top function.

\section{Nature conservation}

Before declaring the whole area - from Den Helder to Esbjerg - as an absolute nature sanctuary, all human uses of the area must be critically evaluated. Considering only the marine part of the Wadden Sea, it will be evident that almost all other human activities and uses of the area interfere with this objective: shipping causes disturbance, pollution and requires dredging; fisheries, executed in the area, meddle with the living resources; harbour facilities claim space and are sources of disturbance and pollution; land reclamation reduces the size of the area. Similar objections can be imagined for activities concerning the construction and maintenance of sea defences, mining, waste disposal, recreation, military training and even scientific research. 
Therefore, reserving the whole area as an absolute sanctuary seems highly impracticable and utterly unrealistic. Besides, history has shown at least some functions to be compatible with a more or less natural state of the area.

\section{Fisheries}

If priority were given to fisheries, interference would be expected from waste disposal, including pollution from harbour sites and activities reducing the size of the area (land reclamation, sea defences). Mining, in particular dredging for sand or shells, might also cause interference because of increased turbidity of the water. However, if fisheries were given priority in all cases, the area might be turned into a maricultural region, for instance for mussels and oysters. As these almost certainly compete for food with other macrobenthic species, the latter would then be considered as vermin and would be exterminated as we do with unwanted species in agriculture; this would affect the bird populations. Therefore, fisheries as the only management objective would seem undesirable.

\section{Recreation}

Recreation as the main management objective for the marine part of the area would signify an increased number of boats - motor and sailing - with the accompanying development of marinas etc. Interference is to be expected from shipping, military training sites (noise), and, as far as sports fishing is concerned, with waste disposal (pollution). However, recreation, if given priority, might cause an increased disturbance in the area, affecting seal and bird populations, increase pollution (organic waste, oil) and claim space (marinas). Moreover, if unrestricted this activity would induce self destruction because of traffic problems and general disturbance.

None of these management objectives is satisfactory in isolation, either because of intolerance for other human uses of the area or, if consistently applied, because it ultimately degrades or even destroys the area as a natural habitat. Therefore, a more subtle and realistic management objective is desirable, which recognizes as a major priority the protection, continued existence and, if necessary, recovery of the natural functions of the Wadden Sea, but allows at the same time various human activities insofar as these do not seriously interfere with natural functions. This is of course a further elaboration of the management strategy with a hierarchical positioning of functions.

Human activities should be evaluated in the light of their possible interference with this management strategy and objective and the protection of the Wadden Sea in general. Social and economical values of these activities will of course play their role in such an evaluation.

A brief and preliminary assessment of the human activities enumerated in the third section concerning their actual or potential interference with a management objective would be as follows:

Sea defences. It is imperative that defences against the sea should be maintained and, where necessary, improved. However, care should be taken to execute the operations with a minimum of damage to the Wadden Sea. This means that improving 
the sea defences is not necessarily identical to reclaiming agricultural land. A new dike behind the existing one could serve the purpose equally well! This could also mean that the material for building new dikes should not be extracted from the Wadden Sea.

Reclamation of land and water-storage basins. Reclamation, either for agricultural purposes or for water-storage basins, is always a loss to the Wadden Sea, and for this reason cannot be reconciled with the management objective as formulated. Moreover, it seems doubtful whether continued land reclamation is feasible. In the past land reclamation has reduced the area to such an extent that new formation of salt marshes becomes even more unlikely. Besides, the hypothesis that a reduction of the Wadden Sea area would affect the size of some North Sea fish and bird populations needs further exploration.

Harbour development. Development of harbours is a serious threat to the area, during both the construction and the operational stages. The influence could probably be minimized by concentration in a few areas and by very strict rules concerning the industries and the pollution levels allowed.

$\mathrm{Sh}$ ipping. Shipping is no major problem as long as it is restricted to a limited number of navigation channels and sea lanes. Very strict measures should be taken to prevent oil spillage, whereas navigation routes should be selected in such a way that minimum dredging would be required.

Mil it a ry tra in in g. Large military training sites can hardly be reconciled with the primary management objective formulated, chiefly because of the widespread disturbance, both to man and nature.

Mining. The question of mining (oil, gas, sand, shells) must be considered very carefully, in particular when the sediment balance of the area might be disturbed. In addition, pollution, especially after accidents (oil, gas), and an increased turbidity level and their effects need attention.

Waste dis charge. This item probably poses one of the most important problems of the Wadden Sea. Although the Wadden Sea ecosystems can tolerate some stress and although waste discharges into the area can be controlled, it seems very likely that during the coming years pollutants will continue to affect the populations of marine mammals and birds. This is because the Wadden Sea has the propensity to accumulate pollutants entering the area via the rivers and the North Sea. This problem will need continuous attention for many years, both from scientists and decision makers. The effect of and counter measures against an oil catastrophy in or near the area should be explored as well.

Recreation. Within limits several forms of recreation can probably find a place in the Wadden Sea area. Studies to evaluate the effect of recreation on the area, with the ultimate aim of designing a maximum allowable recreation level, are urgently needed.

$\mathrm{F}$ is heries. With a number of restrictions several kinds of fisheries seem allowable in the Wadden Sea, especially in the tidal channels. The old conflict of the shrimp fisheries in the area and their interference with the nursery function of the Wadden Sea should be resolved on the basis of continued research. This applies also to the more recent possible conflict between the cockle fisheries and the food supply of shore birds and flatfishes. The effects of mariculture projects (mussels, oysters) on the ecosystems require attention.

$\mathrm{Sc}$ ientif i r e se a $\mathrm{ch}$. For proper management of the area scientific research is 
indispensable and therefore should be allowed. Research not related to management problems can also be admitted, since the few conflicts arising may be solved easily.

It is useful to split up the latter eight functions of the Wadden Sea proper in three categories, viz. (1) functions without impact on other functions; (2) functions with impact, but dependent on a well-functioning Wadden Sea ecosystem; (3) functions with impact and not dependent on the Wadden Sea ecosystem.

The first group is easily reconcilable with the management objective chosen, whereas the latter category requires great caution. To the first group one may bring the nursery function of the Wadden Sea for North Sea fishes as well as the warning function for environmental deterioration. All other major functions belong to the second or third group.

At first glance it seems that the second group deserves less care when allowed in the Wadden Sea than the third group, since the former possesses a negative feed-back to the functioning of ecosystem (e.g. fisheries). However, since both groups of functions are subjected to economic and social factors, this difference between groups becomes largely academic and offers no help in formulating a management strategy.

The management objective formulated in this paper should apply to the whole Wadden Sea area, since this area acts in many respects as an entity concerning such aspects as fisheries, nurseries, bird and seal populations and pollution. When violations of the management objective are considered, the whole area should be taken into account.

A complication is that the area falls under the jurisdiction of three sovereign states. In view of the unity of the Wadden Sea area the implementation of a management goal, as defined here, could be most effectively executed by an international Wadden Sea authority. Such an authority could also evaluate all proposed new activities against the management objective.

Finally, it has to be stressed that both the adoption of a management objective and the decision as to which violations of this objective are to be allowed are political decisions. Scientists can and must guide the way, but they should not take responsibilities which in our governmental system belong to politicians.

\section{PRESENT SITUATION}

The present practice bears the character of a preliminary situation, which could develop in the direction of a management objective as indicated.

In all countries concerned there are governmental declarations and decisions indicating that protection of the area is considered as a reasonable objective. Major human activities are already evaluated in terms of environmental impact, safety aspects (defence against the sea) and economic feasibility. Cooperation between scientists of the three countries, in trying to evaluate the present knowledge of the area and to indicate the most serious dangers, was established during some formal meetings (held at Bremerhaven, 1971, Schiermonnikoog, 1975, and Ribe, 1979) and less formally in the International Wadden Sea Working Group. Various recommendations concerning the unique position of the area in relation to various groups of birds have been formulated by international organizations such as the International Union for the Conservation of Nature and Natural Resources (IUCN). What is still lacking is a declaration of intent 
concerning the area by the governments involved and ways and means of implementing these intents. But negotiations are proceeding and ultimately such a treaty concerning the Wadden Sea might be ratified, hopefully indicating ways and means of effecting the intents laid down in the treaty.

However, notwithstanding these rather optimistic prospects, the present-day practice reveals a number of shortcomings which are likely to persevere in a future situation.

These shortcomings concern mainly two items. One problem is that for an intended new human activity it is often very difficult to indicate, especially in quantitative terms, the environmental effects. At present an environmental or other detrimental effect has to be clearly demonstrated before it is considered in the ultimate decision-making. This procedure should be reversed as soon as possible; it should be the case that a new or intensified human activity must be proven to have no detrimental effect.

The second problem in present-day practice is that human activities in the area often cause irreversible changes. This is obvious in the case of major enclosures of sea areas (Leybucht, Lauwerszee, Zuiderzee etc.), but is also true for the development of large harbour and industrial facilities. Therefore, even when out of every ten proposals for activities only one is granted, the area will slowly degrade and the only achievement of the proposed practice will be that the degradation of the area will have been retarded, but not prevented.

\section{LITERATURE CITED}

Anonymous, 1974. Rapport van de Waddenzeecommissie. Staatsuitgeverij, 's-Gravenhage, 328 pp. Bennekom, A. J. van \& Tijssen, S. B., 1976. Lage zuurstofgehaltes in het water op het Balgzand. $\mathrm{H}_{2} \mathrm{O}$ 9, 28-31.

Berk, S. G., Brownlee, D. C., Heinle, D. R., Kling, H. J. \& Colwell, R. R., 1977. Ciliates as a food sources for marine planktonic copepods. - Microb. Ecol. 4, $27-40$.

Beukema, J. J., 1973. Migration and secondary spatfall of Macoma balthica (L.) in the western part of the Wadden Sea. - Neth. J. Zool. 23, 356-357.

Beukema, J. J., 1976. Biomass and species richness of the macrobenthic animals living on the tidal flats of the Dutch Wadden Sea. - Neth. J. Sea Res. 10, 236-261.

Breteler, W. C. M. Klein, 1976. Settlement, growth and production of the shore crab, Carcinus maenas, on tidal flats in the Dutch Wadden Sea. - Neth. J. Sea Res. 10, 354-476.

Cadée, G. C. \& Hegeman, J., 1974a. Primary production of phytoplankton in the Dutch Wadden Sea. - Neth. J. Sea Res. 8, 240-259.

Cadée, G. C. \& Hegeman, J., 1974b. Primary production of the benthic microflora living on the tidal flats in the Dutch Wadden Sea. - Neth. J. Sea Res. 8, 260-291.

Dankers, N. M. J. A. \& Veen, J. F. de, 1979. Variations in relative abundance in a number of fish species in the Wadden Sea and the North Sea coastal areas. In: Fishes and fisheries of the Wadden Sea. Ed. by N. Dankers, W. J. Wolff \& J. J. Zijlstra. Balkema, Rotterdam, 77-105.

Duinker, J. C. \& Koeman, J. H., 1978. Summary report on the distribution and effects of toxic pollutants (metal and chlorinated hydrocarbons) in the Wadden Sea. In: Pollution of the Wadden Sea area. Ed. by K. Essink \& W. J. Wolff. Balkema, Rotterdam, 45-54.

Essink, K. \& Wolf, P. de, 1978. Pollution by organic waste in the Dutch Wadden Sea and the EmsDollard estuary. In: Pollution of the Wadden Sea area. Ed. by K. Essink \& W. J. Wolff. Balkema, Rotterdam, 39-45.

Es, F. B, van, 1977. A preliminary carbon budget for a part of the Ems estuary: The Dollard. Helgoländer wiss. Meeresunters. 30, 283-294.

Farke, H., Wilde, P. A. W. J. de \& Berghuis, E. Distribution or nursery grounds of Arenicola marina around the island of Texel. - Neth. J. Sea Res. 13. (In press.)

Fenchel, T. M. \& Jørgensen, B. Barker, 1977. Detritus food chains of aquatic ecosystems: the role of bacteria. - Adv. Microbiol. Ecol. 1, 1-58. 
Fransz, G. Quantitative data on the plankton communities of the Wadden Sea proper. In: Invertebrates of the Wadden Sea. Ed. by N. Dankers, H. Kühl \& W. J. Wolff. Balkema, Rotterdam. (In press.)

Groot, S. J. de \& Postma, H., 1968. The oxygen content of the Wadden Sea. - Neth. J. Sea Res. 4, $1-10$.

Hoek, C. van der, Admiraal, W., Colijn, F. \& Jonge, V. N. de, 1979. The role of algae and seagrasses in the Wadden Sea: a review. In: Flora and vegetation of the Wadden Sea. Ed. by W. J. Wolff. Balkema, Rotterdam, 9-118.

Hulscher, J., 1976. Localisation of cockles (Cardium edule L.) by the oystercatcher (Haemotopus ostralegus L.) in darkness and daylight. - Ardea 64, 292-310.

Jacobsen, N. Kingo, 1976. Outline and evaluation of the threats to the natural ecosystems of the Danish Wadden Sea area. In: Proceedings of the conference of Wadden Sea experts, Schiermonnikoog. Ed, by W. J. Wolff. Staatsuitgeverij, 's-Gravenhage, 35-47.

Joenje, W. \& Wolff, W. J., 1979. The functional role of salt marshes in the Wadden Sea. In: Flora and vegetation of the Wadden Sea. Ed. by W. J. Wolff. Balkema, Rotterdam, 161-170.

Jonge, V. N. de \& Postma, H., 1974. Phosphorus compounds in the Dutch Wadden Sea. - Neth. J. Sea Res. 8, 139-153.

Koeman, J. H., 1971. Het voorkomen en de toxicologische betekenis van enkele chloorkoolwaterstoffen aan de Nederlandse kust in de periode 1965 tot 1970 . Thesis, Utrecht, $136 \mathrm{pp}$.

Kuipers, B. R., 1975. Experiments and field observations on the daily food intake of juvenile plaice, Pleuronectes platessa L. In: Ninth European marine biology symposium. Ed.: H. Barnes. Aberdeen Univ. Press, Aberdeen, 1-12.

Linke, O., 1939. Biota des Jadebusenwattes. - Helgoländer wiss. Meeresunters. 1, $201-348$.

McIntyre, A. D., 1978. The benthos of the western North Sea. - Rapp. P. -v. Réun. Cons. int. Explor. Mer. $172,405-417$.

Postma, H, 1954. Hydrography of the Dutch Wadden Sea. - Archs néerl. Zool. 10, 405-511.

Postma, H., 1961. Transport and accumulation of suspended matter in the Dutch Wadden Sea. Neth. J. Sea Res. 1, 148-190.

Postuma, K. H. \& Rauck, G, 1978. The fishery in the Wadden Sea. In: Fishes and fisheries of the Wadden Sea. Ed. by N. Dankers, W. J. Wolff \& J. J. Zijlstra. Balkema, Rotterdam, 139-157.

Rauck, G. \& Zijlstra, J. J., 1978. On the nursery aspects of the Waddensea for some commercial fish species and possible long-term changes. - Rapp. P. - v. Réun. Cons. int. Explor. Mer. 172, 266-275.

Reijnders, P. J. H., 1976. The harbour seal (Phoca vitulina) population in the Dutch Wadden Sea: size and composition. - Neth. J. Sea Res. 10, 223-235.

Reise, K, 1977a. Predation pressure and community structure of an intertidal soft-bottom fauna. In: Biology of benthic organisms. Ed. by B. F. Keegan, P. O. Ceidigh \& P. J. S. Boaden. Pergamon Press, Oxford, 513-519.

Reise, K., $1977 \mathrm{~b}$. Predator exclusion experiments in an intertidal mud flat. - Helgoländer wiss. Meeresunters. 30, 263-271.

Reise, K, 1978. Experiments on epibenthic predation in the Wadden Sea. - Helgoländer wiss. Meeresunters, 31, 55-101.

Rooth, J., 1966. Vogeltellingen in het gehele Nederlandse waddengebied, augustus 1963. - Limosa 39, 175-181.

Rooth, J. \& Donkers, D. A., 1972. The status of some piscivorous birds in the Netherlands. - T. N. O. Nieuws 27, 551-555.

Saeijs, H. L. F. \& Baptist, H. J. M., 1978. Evaluatie van Westeuropese overwinteringsgebieden van watervogels. Nota Rijkswaterstaat Deltadienst afd. Milieuonderzoek, 10, 1-66.

Smidt, E. L. B., 1951. Animal production in the Danish Wadden Sea. - Meddr Kommn Danm. Fisk. og Havunders. (Fisk.) 11 (6), 1-151.

Straaten, L. M. J. U. van, 1965. Coastal barrier deposits in South and North-Holland. - Meded. geol. Sticht., 17, 41-75.

Swennen, C., 1971. Het voedsel van de groenpootruiter Tringa nebularia tijdens het verblijf in het Nederlandse Waddengebied. - Limosa 44, 71-83.

Swennen, C., 1972. Chlorinated hydrocarbons attacked the Eider population in the Netherlands. T. N. O. Nieuws $27,556-560$. 
Swennen, C., 1976a. Populatiestructuur en voedsel van de eidereend Somateria m. mollissima in de Nederlandse Waddenzee. - Ardea 64, 311-371.

Swennen, C., 1976b. Wadden Seas are rare, hospitable and productive. In: Proceedings of the int. conf. conservation of wetlands and waterfowl, Heiligenhafen, 1974. Ed. by M. Smart. Intern. Waterfowl Research Bureau, Slimbridge, 184-198.

Tiews, K., 1978. The German industrial fisheries in the North Sea and their by-catches. - Rapp. P. v. Réun. Cons. int. Explor. Mer. 172, 230-238.

Verweij, J., 1952. On the ecology of the distribution of cockle and mussel in the Dutch Waddensea, their role in sedimentation and the source of their food supply. - Archs neerl. Zool. 10, 171-239.

Vosjan, J. H., 1974. Sulphate in water and sediment of the Dutch Wadden Sea. - Neth. J. Sea Res. 8 , 208-213.

Vosjan, J. \& Olanczuk-Neyman, K. M., 1977. Vertical distribution of mineralization processes in a tidal sediment. - Neth. J. Sea Res. 11, 14-23.

Wellershaus, S., 1978. Transport of pollutants from the freshwater regime to the Wadden Sea through rivers. In: Pollution of the Wadden Sea area. Ed. by K. Essink \& W. J. Wolff. Balkema, Rotterdam, 15-24.

Zijlstra, J. J., 1972. On the importance of the Waddensea as a nursery area in relation to the conservation of the southern North Sea fishery resources. - Symp. zool. Soc. Lond. 29, 233-258.

Zimmerman, J. T. F., 1976. Mixing and flushing of tidal embayments in the western Dutch Wadden Sea. I. Distribution of salinity and calculation of mixing time scales. - Neth. J. Sea Res. 10, 149-191. 